\title{
Pengaruh Independensi Keahlian Profesi Motivasi Kerja Pengalaman Kerja Dan Tingkat Pendidikan Terhadap Kinerja Pengawas Koperasi
}

\author{
Putu Kodyawati ${ }^{1}$ \\ Luh Gede Krisna Dewi ${ }^{2}$ \\ ${ }^{1,2}$ Fakultas Ekonomi dan Bisnis Universitas Udayana (Unud), Bali, Indonesia \\ e-mail: putukodyawati@gmail.com
}

\begin{abstract}
ABSTRAK
Tujuan penelitian ini adalah untuk memperoleh bukti empiris pengaruh independensi, keahlian profesi, motivasi kerja, pengalaman kerja dan tingkat pendidikan terhadap kinerja pengawas koperasi di Kecamatan Klungkung. Penelitian ini dilakukan di seluruh koperasi yang ada di Kecamatan Klungkung. Populasi yang ada berjumlah 126 pengawas. Jumlah sampel yang diambil sebanyak 66 pengawas dengan metode purposive sampling. Pengumpulan data dilakukan melalui survei dan kuesioner. Teknik analisis yang digunakan adalah regresi linear berganda. Berdasarkan hasil analisis ditemukan bahwa independensi, keahlian profesi, motivasi kerja, pengalaman kerja dan tingkat pendidikan secara simultan berpengaruh positif terhadap kinerja pengawas. Secara parsial bahwa independensi, keahlian profesi, motivasi kerja, pengalaman kerja dan tingkat pendidikan juga berpengaruh terhadap kinerja pengawas.
\end{abstract}

Kata kunci : Independensi, kehalian profesi, motivasi kerja.

\begin{abstract}
The purpose of this study was to obtain empirical evidence of the effect of independence, professional expertise, work motivation, work experience and level of education on the performance of cooperative supervisors in Klungkung District. This research was carried out in all cooperatives in Klungkung District. The population is 126 supervisors. The number of samples taken was 66 supervisors with a purposive sampling method. Data collection is done through surveys and questionnaires. The analysis technique used is multiple linear regression. Based on the results of the analysis it was found that independence, professional expertise, work motivation, work experience and education level simultaneously had a positive effect on supervisor performance. Partially that independence, professional expertise, work motivation, work experience and level of education also influence the performance of supervisors.

Keywords: Independence, professional proficiency, motivation
\end{abstract}

\section{PENDAHULUAN}

Salah satu keberhasilan koperasi dapat dilihat dari kinerja pengawas. Kinerja merupakan gambaran mengenai tingkat pencapaian pelaksanaan suatu program kegiatan atau kebijakan dalam mewujudkan sasaran, tujuan, visi, dan misi organisasi yang dituangkan melalui perencanaan strategis suatu organisasi. Kinerja merupakan perilaku nyata yang ditampilkan setiap orang sebagai prestasi 
Putu Kodyawati dan Luh Gede Krisna Dewi. Pengaruh ...

kerja yang dihasilkan oleh pengawas sesuai dengan perannya dalam instansinya (Karma, 2017).

Kinerja seorang pengawas dapat dilihat dari pelaksanaan tugas dan wewenang. Pengawas bertugas untuk melakukan pengawasan terhadap pengelolaan koperasi. Pengawasan merupakan salah satu unsur penting dalam rangka menjawab penilaian kinerja atas pelaksanaan kebijaksanaan koperasi (Bondan, 2017). Pengawasan berfungsi membantu agar sasaran yang ditetapkan koperasi dapat tercapai, serta berperan dalam mendeteksi secara dini terjadinya penyimpangan pelaksanaan, penyalahgunaan wewenang, pemborosan dan kebocoran (Agus dan Trisna, 2017). Berdasarkan I Gede Indra Dewa Putra selaku Kepala Dinas Koperasi dan UKM Provinsi Bali (jarrakpos.com) kinerja pengawas koperasi tidak berjalan dengan baik akan berakibat fatal pada keberlangsungan koperasi berujung pada pembubaran koperasi.

Fenomena yang dapat diamati dalam perkembangan koperasi dewasa ini adalah maraknya pembubaran sejumlah koperasi di Bali. Menurut I Gede Indra Dewa Putra selaku Kepala Dinas Koperasi dan UKM Provinsi Bali (Tribunbali.com) meningkatnya jumlah pembubaran koperasi di Bali merujuk pada pengelolaan koperasi buruk. Jumlah koperasi di Bali secara kesuluruh pada tahun 2018 terdapat 4.850 dengan jumlah tidak aktif mencapai 567 koperasi. Tahun 2018 terdapat 169 koperasi yang dibubarkan dikarenakan pengelolaan koperasi yang kurang terlaksana dengan baik, seperti tidak melaksanakan rapat anggota tahunan (RAT). 
Rapat anggota tahunan merupakan pemegang utama dalam koperasi. Berdasarkan Anggaran Dasar Anggaran Rumah Tangga (AD/ART) Koperasi tujuan dilaksanakan RAT adalah mempertanggungjawabkan pengelolaan koperasi terhadap anggota, mengukur kinerja pengurus koperasi mengenai perkembangan Sisa Hasil Usaha (SHU). Namun banyak koperasi yang tidak melaksanakan RAT di Bali (bali.antara.news). Pengawas koperasi merupakan kompenen penting untuk melihat kinerja koperasi secara keseluruhan terkait pelaksanaan dan pengelolaan berdasarkan Undang-Undang No 25 Tahun 1992 pada pasal 39.

Masalah pembubaran sejumlah koperasi yang ada didaerah menyita perhatian publik, bahkan berimplikasi pada penyelidikan tim khusus yang diturunkan oleh Dinas Koperasi dan UKM Provinsi Bali. Dari sembilan Kabupaten yang ada di Provinsi Bali, beberapa kabupaten pernah menjadi sorotan masyarakat dan media tentang terjadinya kasus pembubaran koperasi hingga koperasi siluman. Salah satu Kabupaten yang menjadi perhatian publik saat ini adalah Kabupaten Klungkung. Menurut Wayan Ardiasa selaku Kepala Dinas Koperasi dan UKM Kabupaten Klungkung (tribunbali.com) mendapati penemuan 14 koperasi siluman dan pembubaran mecapai 28 koperasi. Jumlah pembubaran koperasi tertinggi berada di Kecamatan Klungkung.

Kecamatan Klungkung memiliki jumlah koperasi terbanyak yaitu 42 koperasi dibandingkan Kecamatan lainnya seperti; Kecamatan Banjarangkan berjumlah 17 koperasi, Kecamatan Nusa Penida berjumlah 21 koperasi, Kecamatan Dawan berjumlah 12 koperasi. Secara periodik jumlah koperasi di Kecamatan Klungkung mengalami peningkatan. Dimana koperasi tersebar di 
Putu Kodyawati dan Luh Gede Krisna Dewi. Pengaruh ...

beberapa dusun yang ada di Kecamatan Klungkung. Namun, peningkatan jumlah koperasi bersamaan dengan peningkatan jumlah koperasi tidak melaksanakan RAT. Menurut Wayan Ardiasa selaku Kepala Dinas Koperasi dan UKM Kabupaten Klungkung (tribunbali.com) koperasi tidak aktif diakibatkan karena beberapa koperasi tidak melaksanaan RAT secara berturut-turut dan pengelolaan koperasi buruk. Adapun jumlah koperasi yang tercatat dari tahun 2016 hingga 2017 nampak pada tabel 1 berikut:

Tabel 1.

Jumlah Koperasi di Kecamatan Klungkung Kapupaten Klungkung Tahun 2016-2017

\begin{tabular}{clrccccc}
\hline \multirow{2}{*}{ No } & \multirow{2}{*}{ Jenis Koperasi } & \multicolumn{3}{c}{2016} & \multicolumn{2}{c}{2017} \\
\cline { 2 - 7 } & & RAT & Tidak RAT & Jumlah & RAT & Tidak RAT & Jumlah \\
\hline 1 & KUD & 4 & 1 & 5 & 2 & 3 & 4 \\
2 & KSP & 8 & 3 & 14 & 17 & 4 & 21 \\
3 & KSU & 9 & 5 & 14 & 10 & 7 & 17 \\
& TOTAL & 21 & 9 & 33 & 29 & 14 & 42 \\
\hline
\end{tabular}

Sumber: Dinas Koperasi dan UKM dan Perdagangan Klungkung, 2018

Berdasarkan Tabel 1 Koperasi Serba Usaha (KSU) dan Koperasi Simpan Pinjam (KSP) merupakan jenis koperasi yang paling banyak, hal tersebut menunjukan bahwa minat masyarakat Kecamatan Klungkung terhadap KSU dan KSP lebih tinggi daripada KUD. Meskipun tertinggi, KSU dan KSP memiliki peningkatan jumlah koperasi yang tidak aktif tertinggi dibandingkan Koperasi Unit Desa (KUD). Kompleksitas aktivitas pada KSU, KSP dan KUD yang dijalankan maka perlu pengawasan secara baik terkait pengelolaan operasional.

Kinerja pengawas koperasi dapat diukur melalui standar kualitas, kuantitas dan ketepatan waktu. Standar yang dimaksud adalah kualitas mutu kerja. Sedangkan kuantitas adalah jumlah hasil kerja yang dihasilkan dalam kurun waktu tertentu. Ketepatan waktu adalah kesesuaian dengan perencanaan, untuk 
menghasilkan kinerja yang memuaskan (Bondan, 2017). Pengawas koperasi berperan sebagai internal auditor. Menurut Munawir (2008:18), internal audit adalah suatu fungsi penilaian independen yang diterapkan dalam suatu organisasi.

Pentingnya eksistensi seorang pengawas koperasi, menuntut mereka untuk memiliki sikap independen dalam melaksanakan tugas khususnya dalam menilai efektivitas pengendalian internal. Pengawas koperasi harus bertindak secara objektif dan integritas yang tinggi dalam melaksanakan tugas sehingga dapat menciptakan pengawasan jujur dan tidak memihak dalam menilai dan mengambil kebijakan terkait pengelolaan koperasi. Pernyataan tersebut didukung oleh penelitian yang dilakukan oleh Yuniarta dan Sinarwati (2015) dalam penelitiannya menunjukkan bahwa independensi berpengaruh positif dan signifikan pada pengendalian intern. Widyantara dkk., (2017) menunjukkan independensi memiliki pengaruh positif terhadap kinerja pengawas LPD di Kecamatan Buleleng. Namun menurut Yadnyana (2009) menyatakan bahwa independensi tidak berpengaruh pada kinerja auditor internal.

Seorang pengawas koperasi juga harus memiliki keahlian profesional. Menurut Boyton \& Kell (2003) menyatakan bahwa pemeriksa intern yang baik adalah mereka yang mempunyai kesanggupan teknis dan pendidikan yang memadai disamping kemampuan untuk menyesuaikan diri, bijaksana, mempunyai ketegasan sikap, jujur, independen, objektif dan mempunyai rasa tanggungjawab. Keahlian profesional adalah tingkat kemahiran dan kecermatan profesionalnya dalam melakukan pemeriksaan terhadap penerapan struktur pendendalian (Bhuwaneswari, 2017). Penelitian yang dilakukan oleh Diah dan Ramantha 
Putu Kodyawati dan Luh Gede Krisna Dewi. Pengaruh ...

(2013) yang membuktikan bahwa keahlian profesional yang dimiliki oleh pengawas berpengaruh positif dan signifikan terhadap kinerja badan pengawas sebagai fungsi auditor internal dalam pengawasan kredit.

Pengawas koperasi diharapkan memiliki motivasi yang besar dalam bekerja atau menjalankan tugasnya sehingga dapat memberikan hasil yang baik untuk kemajuan koperasi itu sendiri. Motivasi adalah keadaan dalam pribadi seseorang yang mendorong keinginan individu untuk melakukan kegiatan tertentu untuk mencapai suatu tujuan (Novita dkk., 2014). Motivasi dapat membuat seseorang mempunyai semangat juang yang tinggi ntuk meraih tujuan dan memenuhi standar yang ada. Semakin tinggi motivasi pengawas internal, semakin membantu pengawas dalam menjalankan tugasnya (Bhuwaneswari, 2017). Hal ini dibuktikan dengan penelitian Bhuwaneswari (2017) yang menyatakan bahwa motivasi mempunyai pengaruh positif terhadap kinerja pengawas internal LPD di Kota Denpasar.

Pengawas koperasi harus memiliki pengalaman kerja. Pengalaman kerja merupakan suatu proses pembelajaran dan pertambahan perkembangan potensi bertingkah laku, baik dari pendidikan formal amupun nonformal. Pengalaman kerja akan semakin meningkat seiring dengan meningkatnya kompleksitas kerja (Bhuwaneswari, 2017). Pengawas koperasi yang berpengalaman akan lebih cepat tanggap dalam mendeteksi kekeliruan yang terjadi. Bertambahnya pengalaman kerja pengawas koperasi juga akan meningkatkan ketelitian dalam melaksanakan pengawasan. Pernyataan tersebut didukung oleh penelitian Diana dan Ramantha (2013) dan Yuniarta dan Sinar Wati (2015) menyatakan bahwa pengalaman kerja 
berpengaruh positif terhadap penerapan struktur pengendalian internal. Penelitian yang dilakukan Budiasih dan Budiartha (2017) juga menunjukkan pengalaman kerja berpengaruh terhadap kinerja pengawas di KAP Provinsi Bali.

Pengawas koperasi berfungsi sebagai internal auditor dalam melaksanakan tugasnya harus senatiasa bertindak sebagai orang yang ahli pada bidangnya. Menurut Lisna (2007:92), pendidikan membentuk dan menambah pengetahuan seseorang untuk mengerjakan sesuatu dengan baik dan lebih cepat. Salah satu penyebab utama pemeriksaan yang dilakukan pengawas internal tidak efektif dan efisien adalah tingkat pendidikan yang tidak merata dan beraneka ragam latar belakang jurusan pendidikan (Andersen dan Lubis, 2009:2). Pengawas internal diukur melalui tingkat pendidikan terakhir yang dimiliki karena disamping pengalaman, semakin tinggi tingkat pendididkan yang dimiliki seorang pengawas, maka pengetahuan yang diperoleh semakin banyak dan dapat mengadakan pengawasan dengan baik (Bhuwaneswari, 2017). Pernyataan tersebut searah dengan penelitian yang dilakukan Bhuwaneswari (2017) menyatakan bahwa tingkat pendidikan berpengaruh positif dan siginifikan pada struktur pengendalian LPD di Kota Denpasar. Namun sebaliknya penelitian Andersen dan Lubis (2019) menyebutkan bahwa tingkat pendidikan berpengaruh negatif pada kualitas hasil pemeriksaan.

Teori atribusi yaitu teori yang mempelajari alasan atas perilaku seseorang. Suartana (2010) menyatakan bahwa atribusi adalah proses mempelajari bagaimana seseorang menyikapi suatu peristiwa dan menjelaskan penyebab atas perilakunya (Suartana, 2010;181). Independensi merupakan salah satu penyebab 
Putu Kodyawati dan Luh Gede Krisna Dewi. Pengaruh ...

perilaku seorang pengawas yang berasal dari dalam diri pengawas. Independensi merupakan indikator internal dalam menjelaskan bagaimana seorang pengawas menjelaskan perilakunya melalui tugas dan wewenang yang dimilikinya. Menurut Halim (2008:47) independensi berarti bebas dari pengaruh, sedang tidak dikendalikan oleh pihak lain dan tidak bergantung pada pihak lain. Setiap pengawas harus memelihara integritas dan obyektivitas dalam tugasnya.

Rahayu (2016) dalam penelitiannya menunjukkan bahwa seorang auditor dipengaruhi oleh independensi dalam menjalankan tugasnya. Sehingga, independensi dianggap penting dalam pelaksanaan tugas dan wewenang seorang auditor. Widyantara dkk., (2017) juga menyatakan dalam penelitiannya independensi berpengaruh positif terhadap kinerja badan pengawas LPD di kecamatan Buleleng. Penelitian yang dilakukan Bayu dan Rasmini (2014) menyebutkan bahwa independensi berpengaruh positif terhadap efektivitas pengawas koperasi di Buleleng. Milica \& Đukić (2017) dalam penelitiannya menyebutkan bahwa independensi berpengaruh positif pada efektivitas auditor internal. Wan dan Sri (2017) dalam penelitiannya pada auditor Kantor Akuntan Publik di Kota Medan menyatakan independensi berpengaruh positif dan signifikan terhadap kualitas penyajian auditor. Pada penelitian Laturkary (2014) menyatakan bahwa auditor internal dalam perusahan saham di Yamen memiliki independensi yang cukup. Hal ini disebabkan karena independensi dianggap penting dalam pelaksaan tugas dan wewenang pada seorang pengawas koperasi selaku auditor internal. Melalui sikap independen seorang pengawas harus bebas dari tekanan apapaun. Ketika auditor menjaga sikap independennya, maka akan 
mengurangi terjadi penyelewengan tugas. Dengan demikian, sikap independen penting dan harus dijunjung tinggi seorang pengawas.

Berdasarkan kajian teoretis dan empiris serta didukung oleh dasar logika, maka hipotesis penelitian yang diajukan adalah:

$\mathrm{H}_{1}$ : Independensi berpengaruh terhadap kinerja pengawas koperasi di Kecamatan Klungkung.

Teori atribusi yaitu teori yang mempelajari alasan atas perilaku seseorang. Suartana (2010) menyatakan bahwa atribusi adalah proses mempelajari bagaimana seseorang menyikapi suatu peristiwa dan menjelaskan penyebab atas perilakunya (Suartana, 2010;181). Keahlian profesi merupakan salah satu penyebab perilaku seorang pengawas yang berasal dari dalam diri pengawas. Keahlian profesi merupakan indikator internal dalam menjelaskan bagaimana seorang pengawas menjelaskan perilakunya melalui tugas dan wewenang yang dimilikinya. Keahlian professional merupakan kemampuan yang dimiliki seorang auditor dalam menjalankan tugasnya sesuai dengan standar profesi. Elemen dari keahlian profesional ini adalah ketaatan terhadap kode etik profesional, pengetahuan, ketrampilan, dan disiplin ilmu, hubungan dan komunikasi antar manusia, dan pendidikan berkelanjutan

Rahayu (2016) dalam penelitiannya menyatakan bahwa keahlian professional berpengaruh positif terhadap kualitas kinerja auditor. Pengujian terhadap pengaruh keahlian profesionalisme terhadap kinerja yang dilakukan oleh Kalbers dan Fogarty (1995) menunjukkan terdapat pengaruh positif, meskipun hanya ditemukan dalam dimensi afiliasi komunitas dan tuntutan kemandirian. Mappanyuki (2016) dalam penelitiannya menyebutkan bahwa keahlian profesi 
Putu Kodyawati dan Luh Gede Krisna Dewi. Pengaruh ...

berpengaruh positif terhadap kompleksitas kinerja seorang auditor. Aditya dan Wirakusuma (2014) dalam penelitiannya menunjukkan bahwa keahlian professional berpengaruh positif dan secara signifikan terhadap kinerja auditor internal. Meilina dkk., (2017) juga menyatakan dalam penelitiannya bahwa keahlian profesi berpengaruh secara positif signifikan terhadap kualitas audit yang dihasilkan. Pengawas yang memiliki keahlian berdasarkan jabatan yang diperoleh saat ini, akan mempermudah dalam menemukan kekeliruan maupun indikasiindikasi penyelewengan dari pengendalian internal koperasi.

Berdasarkan kajian teoretis dan empiris serta didukung oleh dasar logika, maka hipotesis penelitian yang diajukan adalah:

$\mathrm{H}_{2}$ : Keahlian profesional berpengaruh terhadap kinerja pengawas di Kecamatan Klungkung.

Teori atribusi yaitu teori yang mempelajari alasan atas perilaku seseorang. Suartana (2010) menyatakan bahwa atribusi adalah proses mempelajari bagaimana seseorang menyikapi suatu peristiwa dan menjelaskan penyebab atas perilakunya (Suartana, 2010;181). Motivasi kerja merupakan salah satu penyebab perilaku seorang pengawas yang berasal dari dalam diri pengawas. Motivasi kerja merupakan indikator internal dalam menjelaskan bagaimana seorang pengawas menjelaskan perilakunya melalui tugas dan wewenang yang dimilikinya. Menurut teori hirarki Maslow jika pekerjaan telah memenuhi beberapa kebutuhan yang lebih tinggi maka hal tersebut akan menentukan dalam motivasi kerja. Tingkat aspirasi sangat berhubungan erat dengan hirarki kebutuhan, dan sikap akan menentukan jalan yang akan ditempuh seseorang untuk pencapaian kebutuhannya 
(Haiman, 2003, 219). Kategori kebutuhan yang paling pokok yang dikemukakan Maslow adalah aktualisasi diri.

Widyantara dkk., (2017) menyebutkan bahwa salah satu faktor yang mempengaruhi kinerja dari badan pengawas (internal auditor) LPD di kecamatan Buleleng adalah motivasi. Herianto dkk., (2017) dalam penelitiannya motivasi juga dikatakan berpengaruh positif terhadap kinerja auditor pada BPK Provinsi Sulawesi Selatan. Hasil penelitian menunjukkan bahwa auditor dipengaruhi oleh motivasi atas penghargaan yang diperoleh dari kinerja di BPK Provinsi Sulawesi Selatan. Semakin tinggi penghargaan yang diberikan maka akan semakin tinggi keinginan bekerja di BPK. Meilina dkk., (2017) menyatakan bahwa motivasi kerja berpengaruh positif terhadap kinerja seorang auditor dalam kualitas audit yang dihasilkan. Arisza (2017) dalam penelitian yang dilakukan di Inspektorat Kabupaten Riau bahwa variabel motivasi kerja berpengaruh terhadap kualitas audit. Hal ini disebabkan motivasi merupakan salah satu faktor penting dalam kinerja pengawas koperasi. Motivasi yang dimiliki seorang pengawas koperasi akan mendukung pengambilan kebijakan maupun keputusan. Motivasi yang dimiliki pengawas tentu bersedia mengerahkan kinerja yang dimiliki secara optimal.

Berdasarkan kajian teoretis dan empiris serta didukung oleh dasar logika, maka hipotesis penelitian yang diajukan adalah:

$\mathrm{H}_{3}$ : Motivasi kerja berpengaruh terhadap kinerja pengawas di Kecamatan Klungkung

Teori atribusi yaitu teori yang mempelajari alasan atas perilaku seseorang. Suartana (2010) menyatakan bahwa atribusi adalah proses mempelajari 
Putu Kodyawati dan Luh Gede Krisna Dewi. Pengaruh ...

bagaimana seseorang menyikapi suatu peristiwa dan menjelaskan penyebab atas perilakunya (Suartana, 2010;181). Pengalaman kerja merupakan salah satu penyebab perilaku seorang pengawas yang berasal dari dalam diri pengawas. Pengalaman kerja merupakan indikator internal dalam menjelaskan bagaimana seorang pengawas menjelaskan perilakunya melalui tugas dan wewenang yang dimilikinya. Pengalaman kerja merupakan faktor penting dalam memprediksi dan menilai kinerja internal auditor dalam melakukan pemeriksaan intern. Pengawas yang berpengalaman akan lebih cepat tanggap dalam mendeteksi kekeliruan yang terjadi. Menurut Koroy (2005:917) semakin berpengalaman seorang internal auditor maka semakin mampu menghasilkan kinerja yang baik dalam tugasnya.

Hal ini dibuktikan oleh penelitian yang dilakukan oleh Yudha dan Mimba, (2017) menujukkan bahwa pengalaman yang dimiliki seorang auditor dapat berpengaruh seignifikan terhadap kualitas audit yang disajikan oleh seorang auditor. Bhargava and Anbazhagan (2014) menyatakan bahwa pengalaman kerja akan meningkatkan efektivitas dalam bekerja namun pengalaman kerja mengalami penurunan pada karyawan lama. Budiasih dan Budiartha (2017) dalam penelitiannya di KAP Provinsi Bali menyatakan bahwa pengalaman kerja memepengaruhi kualitas auditor. Penelitian terkait pengalaman kerja, juga didukung oleh penelitian Wan dan Sri (2017). Penelitian yang dilakukan oleh Wan dan Sri menyatakan bahwa pengalaman secara simultan berpengaruh terhadap kualitas audit. Sedangkan Dhiaa dan Thuraiya (2017) dalam penelitiannya yang mana salah satu variabel independen adalah pengalaman kerja tidak berpengaruh pada efektivitas pelaksanaan internal audit. Arisza (2017) 
menyatakan bahwa kualitas audit yang disajikan seorang auditor tidak dipengaruhi oleh pengalaman kerja yang dimiliki. Bouhawia dkk (2015) menyebutkan bahwa pengalaman kerja tidak berpengaruh pada hasil audit dan hanya menghasilkan efek yang berlawanan pada integritas auditor. Hal ini dapat terjadi karena pengalaman tersebut membentuk seorang auditor yang ahli dalam mengaudit secara teknis maupun psikis. Pengalaman yang diperoleh akan digunakan dengan baik oleh auditor dalam melakukan pekerjaan yang selanjutnya, sehungga hasil auditnya akan lebih berkualitas daripada sebelumnya

Berdasarkan kajian teoretis dan empiris serta didukung oleh dasar logika, maka hipotesis penelitian yang diajukan adalah:

$\mathrm{H}_{4}$ : Pengalaman kerja berpengaruh terhadap kinerja pengawas di Kecamatan Klungkung

Teori atribusi yaitu teori yang mempelajari alasan atas perilaku seseorang. Suartana (2010) menyatakan bahwa atribusi adalah proses mempelajari bagaimana seseorang menyikapi suatu peristiwa dan menjelaskan penyebab atas perilakunya (Suartana, 2010;181). Pendidikan merupakan salah satu penyebab perilaku seorang pengawas yang berasal dari dalam diri pengawas. Pendidikan merupakan indikator internal dalam menjelaskan bagaimana seorang pengawas menjelaskan perilakunya melalui tugas dan wewenang yang dimilikinya. Pengetahuan diukur dari seberapa tinggi pendidikan seorang auditor. Menurut Lisna (2007:92) pendidikan membentuk dan menambah pengetahuan seseorang untuk mengerjakan sesuatu lebih baik dan tepat. Seorang pengawas koperasi dalam melaksanakan kegiatan pengawasannya harus mempunyai pendidikan, keahlian dan disiplin. Pegawas koperasi yang ahli akan bekerja dengan teliti dan 
Putu Kodyawati dan Luh Gede Krisna Dewi. Pengaruh ...

mengetahui dengan cepat penyimpangan yang terjadi dan tepat waktu dalam melaksanakan pengawasan.

Hal ini diungkap dalam penelitian Widyantara dkk., (2017) yang dilakukan pada pengawas LPD di kecamatan Buleleng. Variabel pendidikan dinyatakan berpengaruh postif terhadap kinerja pengawas LPD tersebut. Bouhawia dkk (2015) menyebutkan bahwa tingkat pendidikan berpengaruh pada hasil audit. Penelitian yang dilakukan oleh Meilina dkk., (2017) menyatakan bahwa pendidikan yang dimiliki seroang auditor berpengaruh terhadap kulitas audit yang dihasilkan. Penelitian yang dilakukan Bhargava dan Anbazhagan (2014) mengungkapkan bahwa faktor pendidikan berpengaruh pada efektivitas kerja yang dilaksanakan. Sehingga, pendidikan sangat penting bagi auditor karena melalui pengetahuan yang diperoleh auditor dapat mempermudah dalam melakukan pemeriksaan audit.

Berdasarkan kajian teoretis dan empiris serta didukung oleh dasar logika, maka hipotesis penelitian yang diajukan adalah:

$\mathrm{H}_{5}$ : Tingkat pendidikan berpengaruh terhadap kinerja pengawas di Kecamatan Klungkung.

\section{METODE PENELITIAN}

Lokasi penelitian ini berada di Kecamatan Klungkung, Kabupaten Klungkung dan ruang lingkupnya adalah Pengawas Koperasi di Kecamatan Klungkung. Pemilihan ruang lingkup berdasar pada : 1) Terdaftar sebagai koperasi berbadan hukum; 2) Melakukan Rapat Anggota Tahunan (RAT); 3) Koperasi berstatus 
aktif. Daftar Pengawas Koperasi di Kecamatan Klungkung diperoleh dari Dinas Koperasi dan UMKM Kabupaten Klungkung.

Populasi dalam penelitian ini yaitu seluruh pengawas koperasi yang ada di Kecamatan Klungkung Kabupaten Klungkung. Metode sampel dalam penelitian ini berdasarkan pada metode non probability sampling dengan menggunakan metode purposive sampling. Oleh karena itu, maka didapatkan sampel yang memenuhi kriteria berjumlah 66 responden.

Penelitian ini menggunakan teknik regresi linear berganda untuk pengolahan dengan bantuan program SPSS for Windows. Teknik ini digunakan untuk mengetahui pengaruh antara variabel bebas terhadap variabel terikatnya, yaitu independensi, keahlian profesional, motivasi kerja, pengalaman kerja dan tingkat pendidikan terhadap kinerja pengawas koperasi di kecamatan Klungkung. Persamaan regresi dalam penelitian ini adalah:

$Y=\alpha+\beta_{1} X_{1}+\beta_{2} X_{2}+\beta_{3} X_{3}+\beta_{4} X_{4}+\beta_{5} X_{5}+e$

Keterangan :

$$
\begin{array}{ll}
\mathrm{Y} & =\text { Kinerja } \\
\alpha & =\text { Kontanta } \\
\beta & =\text { Koefisien Regresi } \\
\mathrm{X}_{1} & =\text { Independensi (Ind) } \\
\mathrm{X}_{2} & =\text { Keahlian Profesional (Ahli) } \\
\mathrm{X}_{3} & =\text { Motivasi Kerja (Mov) } \\
\mathrm{X}_{4} & =\text { Pengalaman Kerja (Peng) } \\
\mathrm{X}_{5} & =\text { Tingkat Pendidikan (Pend) } \\
\mathrm{e} & =\text { Tingkat Error }
\end{array}
$$


Putu Kodyawati dan Luh Gede Krisna Dewi. Pengaruh ...

\section{HASIL DAN PEMBAHASAN}

Berdasarkan hasil olahan SPSS 20 yang meliputi variabel independensi, keahlian profesi, motivasi kerja, pengalaman kerja dan tingkat pendidikan didapat hasil analisis data untuk statistik deskriptif yang dapat dilihat pada Tabel 2.

Tabel 2.

Hasil Statistik Deskriptif

\begin{tabular}{lcrrrr}
\hline & $\mathrm{N}$ & \multicolumn{1}{c}{ Minimum } & Maximum & Mean & Std. Deviation \\
\hline Independensi & 66 & 10,00 & 16,00 & 13,0758 & 1,84233 \\
Keahlian Profesi & 66 & 12,00 & 16,00 & 14,0758 & 1,44978 \\
Motivasi Kerja & 66 & 12,00 & 16,00 & 14,3636 & 1,19790 \\
Pengalaman Kerja & 66 & 15,00 & 20,00 & 18,3636 & 1,44261 \\
Tingkat Pendidikan & 66 & 7,00 & 12,00 & 10,7121 & 1,18666 \\
Kinerja & 66 & 38,00 & 43,00 & 40,5909 & 0,97629 \\
Valid N (listwise) & 66 & & & & \\
\hline Sumber: Data diolah, 2018 & & &
\end{tabular}

Berdasarkan statistik deskriptif yang ditunjukkan Tabel 2 digunakan nilai terendah dari besaran independensi sebesar 10,00 dan nilai tertinggi sebesar 16,00. Nilai rata-rata dari besaran independensi adalah 13,07. Ini menunjukkan bahwa nilai rata-rata variabel independensi mendekati nilai maksimum daripada nilai minimumnya Hal ini berarti rata-rata responden berpendapat bahwa indikator independensi cenderung menyebabkan kinerja pengawas meningkat. Nilai standar deviasi sebesar 1,84 yang tidak melebihi dua kali rata-ratanya menunjukkan bahwa sebaran data dapat dikatakan baik.

Berdasarkan statistik deskriptif yang ditunjukkan Tabel 2 digunakan nilai terendah dari besaran keahlian profesi sebesar 12,00 dan nilai tertinggi sebesar 16,00. Nilai rata-rata dari besaran keahlian profesi adalah 14,07. Ini menunjukkan bahwa nilai rata-rata variabel keahlian profesi mendekati nilai maksimum daripada nilai minimumnya Hal ini berarti rata-rata responden berpendapat bahwa indikator keahlian profesi cenderung menyebabkan kinerja pengawas meningkat. 
Nilai standar deviasi sebesar 1,44 yang tidak melebihi dua kali rata-ratanya menunjukkan bahwa sebaran data dapat dikatakan baik.

Berdasarkan statistik deskriptif yang ditunjukkan Tabel 2 digunakan nilai terendah dari besaran motivasi kerja sebesar 12,00 dan nilai tertinggi sebesar 16,00. Nilai rata-rata dari besaran motivasi kerja adalah 14,36. Ini menunjukkan bahwa nilai rata-rata variabel independensi mendekati nilai maksimum daripada nilai minimumnya. Hal ini berarti rata-rata responden berpendapat bahwa indikator motivasi cenderung menyebabkan kinerja pengawas meningkat. Nilai standar deviasi sebesar 1,44 yang tidak melebihi dua kali rata-ratanya menunjukkan bahwa sebaran data dapat dikatakan baik.

Berdasarkan statistik deskriptif yang ditunjukkan Tabel 2 digunakan nilai terendah dari besaran pengalaman kerja sebesar 15,00 dan nilai tertinggi sebesar 20,00. Nilai rata-rata dari besaran pengalaman kerja adalah 18,36. Ini menunjukkan bahwa nilai rata-rata variabel pengalaman kerja mendekati nilai maksimum daripada nilai minimumnya Hal ini berarti rata-rata responden berpendapat bahwa indikator pengalaman kerja cenderung menyebabkan kinerja pengawas meningkat. Nilai standar deviasi sebesar 1,44 yang tidak melebihi dua kali rata-ratanya menunjukkan bahwa sebaran data dapat dikatakan baik.

Berdasarkan statistik deskriptif yang ditunjukkan Tabel 2 digunakan nilai terendah dari besaran tingkat pendidikan sebesar 7,00 dan nilai tertinggi sebesar 12,00. Nilai rata-rata dari besaran tingkat pendidikan adalah 10,71. Ini menunjukkan bahwa nilai rata-rata variabel tingkat pendidikan mendekati nilai maksimum daripada nilai minimumnya Hal ini berarti rata-rata responden 
Putu Kodyawati dan Luh Gede Krisna Dewi. Pengaruh ...

berpendapat bahwa indikator tingkat pendidikan cenderung menyebabkan kinerja pengawas meningkat. Nilai standar deviasi sebesar 1,18 yang tidak melebihi dua kali rata-ratanya menunjukkan bahwa sebaran data dapat dikatakan baik.

Berdasarkan statistik deskriptif yang ditunjukkan Tabel 2 digunakan nilai terendah dari kinerja pengawas sebesar 38,00 dan nilai tertinggi sebesar 43,00. Nilai rata-rata dari kinerja pengawas adalah 40,59. Ini menunjukkan bahwa nilai rata-rata variabel kinerja pengawas mendekati nilai maksimum daripada nilai minimumnya. Hal ini menandakan bahwa rata-rata kinerja pengawas di Koperasi Kecamatan Klungkung tinggi. Nilai standar deviasi sebesar 0,97 yang tidak melebihi dua kali rata-ratanya menunjukkan bahwa sebaran data dapat dikatakan baik.

Berdasarkan Tabel 3 dapat dilihat persamaan regresi linear bergandanya sebagai berikut:

Tabel 3.

Hasil Analisis Regresi Linear Berganda

\begin{tabular}{|c|c|c|c|c|c|}
\hline \multirow[t]{2}{*}{ Model } & \multicolumn{2}{|c|}{ Unstandardized Coefficients } & \multirow{2}{*}{$\begin{array}{c}\text { Standardized } \\
\text { Coefficients } \\
\text { Beta }\end{array}$} & \multirow{2}{*}{$T$} & \multirow{2}{*}{ Sig. } \\
\hline & $B$ & Std. Error & & & \\
\hline (Constant) & 19,636 & 0,892 & & 22,022 & 0,000 \\
\hline Independensi & 0,191 & 0,021 & 0,360 & 9,155 & 0,000 \\
\hline Keahlian Profesi & 0,312 & 0,027 & 0,464 & 11,472 & 0,000 \\
\hline Motivasi Kerja & 0,419 & 0,033 & 0,514 & 12,868 & 0,000 \\
\hline Pengalaman Kerja & 0,198 & 0,027 & 0,292 & 7,442 & 0,000 \\
\hline Tingkat Pendidikan & 0,411 & 0,033 & 0,500 & 12,491 & 0,000 \\
\hline Adjusted $R$ Square & & & 0,903 & & \\
\hline Sig. $F$ & & & 0,000 & & \\
\hline
\end{tabular}

Sumber: Data diolah, 2018

Berdasarkan Tabel 3 beberapa hal yang dapat diketahui persamaan dari analisis regresi linear berganda yaitu :

$Y=19,636+0,191 X_{1}+0,312 X_{2}+0,419 X_{3}+0,198 X_{4}+0,411 X_{5}+e$ 
Nilai konstanta sebesar 19,636 menunjukkan bahwa variabel independensi (Ind), keahlian profesi (Ahli), motivasi kerja (Mov), pengalaman kerja (Peng) dan tingkat pendidikan (Pend) sama dengan nol (tetap atau tidak berubah), menyebabkan peningkatan kinerja pengawas koperasi $(\mathrm{Y})$ sebesar konstantanya yaitu 19,636 .

Nilai koefisien $\beta_{1}=0,191$ menunjukkan bila independensi (Ind) bertambah satu satuan, maka kinerja pengawas (Y) akan mengalami peningkatan sebesar 0,191 satuan dengan asumsi variabel bebas lainnya konstan.

Nilai koefisien $\beta_{2}=0,321$ menunjukkan bila keahlian profesi (Ahli) bertambah satu satuan, maka kinerja pengawas (Y) akan mengalami peningkatan sebesar 0,321 satuan dengan asumsi variabel bebas lainnya konstan.

Nilai koefisien $\beta_{3}=0,419$ menunjukkan bila motivasi kerja (Mov) bertambah satu satuan, maka kinerja pengawas (Y) akan mengalami peningkatan sebesar 0,419 satuan dengan asumsi variabel bebas lainnya konstan.

Nilai koefisien $\beta_{4}=0,198$ menunjukkan bila pengalaman kerja (Peng) bertambah satu satuan, maka kinerja pengawas (Y) akan mengalami peningkatan sebesar 0,198 satuan dengan asumsi variabel bebas lainnya konstan.

Nilai koefisien $\beta_{5}=0,411$ menunjukkan bila tingkat pendidikan (Pend) bertambah satu satuan, maka kinerja pengawas (Y) akan mengalami peningkatan sebesar 0,411 satuan dengan asumsi variabel bebas lainnya konstan.

Dari ketiga variabel diketahui bahwa variabel motivasi kerja (Mov) memiliki nilai koefisien beta standardized yang paling tinggi yaitu 0,514 , sedangkan variabel yang paling kecil adalah pengalaman kerja (Peng) sebesar 
Putu Kodyawati dan Luh Gede Krisna Dewi. Pengaruh ...

0,292. Dengan demikian variabel motivasi kerja (Mov) adalah variabel yang berpengaruh dominan terhadap kinerja pengawas (Y).

Kooefisien determinasi yang digunakan pada analisis regresi linear berganda adalah nilai Adjust $\mathrm{R}^{2}$. Penelitian ini tidak menggunakan $\mathrm{R}^{2}$ dikarenakan terdapat lebih dari satu variabel independen. Hasil penyajian dapat dilihat pada Tabel 4 sebagai berikut.

Tabel 4.

Hasil Koefisien Determinasi Model

\begin{tabular}{ccccc}
\hline Model & $\mathrm{R}$ & $\mathrm{R}$ Square & Adjusted R Square & Std. Error of the Estimate \\
\hline 1 & 0,954 & 0,91 & 0,903 & 0,30452 \\
\hline \multicolumn{2}{l}{ Sumber: Data diolah, 2018} & &
\end{tabular}

Berdasarkan table 4 hasil analisis menunjukkan nilai sebesar 0,903. Ini berarti perubahan yang terjadi pada kinerja pengawas dapat dijelaskan oleh independensi (Ind), keahlian profesi (Ahli), motivasi kerja (Mov), pengalaman kerja (Peng) dan tingkat pendidikan (Pend) sebesar 90,3 persen, sedangkan sisanya 9,7 persen dijelaskan oleh faktor lain yang tidak diuji dalam penelitian ini.

Tabel 5.

Hasil uji Kelayakan Model

\begin{tabular}{|c|c|c|c|c|c|c|}
\hline \multicolumn{2}{|r|}{ Model } & Sum of Squares & Df & Mean Square & $\mathrm{F}$ & Sig. \\
\hline \multirow[t]{3}{*}{1} & Regression & 56,391 & 5 & 11,278 & 121,624 & 0,00 \\
\hline & Residual & 5,564 & 60 & 0,093 & & \\
\hline & Total & 61,955 & 65 & & & \\
\hline
\end{tabular}

Sumber: Data diolah, 2018

Berdasarkan Tabel 5 dapat dilihat bahwa pada model memiliki nilai sig sebesar 0,00 lebih kecil dari nilai $\alpha=0,05$ menunjukkan model penelitian ini layak untuk digunakan sebagai alat analisis untuk menguji pengaruh variabel independen terhadap variabel independen. Hal ini dapat dikatakan bahwa variabel independensi (Ind), keahlian profesi (Ahli), motivasi kerja (Mov), pengalaman 
kerja (Peng), tingkat pendidikan (Pend) berpengaruh secara bersama-sama terhadap variabel dependennya yaitu kinerja pengawas (Y).

Uji statistik t pada dasarnya menunjukkan seberapa jauh pengaruh satu variabel bebas secara individual dalam menerangkan variasi variabel terikat. Uji statistik dilakukan dengan membandingkan hasil nilai siginifikansi 0,05 dan dapat dijelaskan sebagai berikut:

Tabel 6.

Hasil Analisis Uji t

\begin{tabular}{ccccc}
\hline Variabel & $\begin{array}{c}\text { Koefisien } \\
\text { Regresi }\end{array}$ & $\mathrm{T}_{\text {hitung }}$ & Sig & Hasil Hipotesis \\
\hline Independensi & 0,191 & 9,155 & 0,00 & $\mathrm{H}_{0}$ ditolak \\
Keahlian Profesi & 0,312 & 11,472 & 0,00 & $\mathrm{H}_{0}$ ditolak \\
Motivasi Kerja & 0,419 & 12,868 & 0,00 & $\mathrm{H}_{0}$ ditolak \\
Pengalaman Kerja & 0,198 & 7,442 & 0,00 & $\mathrm{H}_{0}$ ditolak \\
Tingkat Pendidikan & 0,411 & 12,491 & 0,00 & $\mathrm{H}_{0}$ ditolak \\
\hline
\end{tabular}

Sumber: Data diolah, 2018

Berdasarkan Tabel 6 diperoleh nilai signifikasi uji t satu sisi untuk variabel independensi (Ind) sebesar 0,000 maka tingkat signifikasi t pada uji satu sisi adalah 0,000 lebih kecil dari $\alpha=0,05$ dan nilai koefisien regresi sebesar 0,191 hal ini mengindikasikan bahwa independensi (Ind) berpengaruh positif dan signifikan pada kinerja pengawas (Y) sehingga hipotesis pertama dalam penelitian ini diterima.

Rahayu (2016) dalam penelitiannya menunjukkan bahwa seorang auditor dipengaruhi oleh independensi dalam menjalankan tugasnya. Sehingga, independensi dianggap penting dalam pelaksanaan tugas dan wewenang seorang auditor. Widyantara dkk., (2017) juga menyatakan dalam penelitiannya independensi berpengaruh positif terhadap kinerja badan pengawas LPD di kecamatan Buleleng. Penelitian yang dilakukan Bayu dan Rasmini (2014) 
Putu Kodyawati dan Luh Gede Krisna Dewi. Pengaruh ...

menyebutkan bahwa independensi berpengaruh positif terhadap efektivitas pengawas koperasi di Buleleng. Pada penelitian Laturkary (2014), Milica \& Đukić (2017), Wan dan Sri (2017), dalam penelitiannya juga menyebutkan bahwa independensi berpengaruh positif pada efektivitas auditor internal.

Hasil penelitian ini sejalan dengan penelitian yang dilakukan oleh Milica \& Đukić (2017) yang menyebutkan bahwa independensi berpengaruh positif terhadap kinerja. Penelitian lain yang diambil dari Bayu dan Rasmini (2014), Laturkary (2014), Rahayu (2016) Widyantara dkk., (2017) menunjukkan hasil yang sama.

Berdasarkan Tabel 5 diperoleh nilai signifikasi uji t satu sisi untuk variabel keahlian profesi (Ahli) sebesar 0,00 maka tingkat signifikasi t pada uji satu sisi adalah 0,00 lebih kecil dari $\alpha=0,05$ dan nilai koefisien regresi sebesar 0,312 hal ini mengindikasikan bahwa keahlian profesi (Ahli) berpengaruh positif dan signifikan pada kinerja pengawas (Y) sehingga hipotesis kedua dalam penelitian ini diterima.

Hasil penelitian ini membuktikan bahwa teori atribusi dan keahlian profesi berpengaruh pada kinerja pengawas. Keahlian professional merupakan kemampuan yang dimiliki seorang auditor dalam menjalankan tugasnya. Keahlian profesional adalah tingkat kemahiran profesional auditor internal dalam melakukan pemeriksaan yang dilaksanakan dengan keterampilan dan kecermatan profesionalnya terhadap penerapan struktur pengendalian. Keahlian profesional yang dimaksudkan adalah kesesuaian dengan standar profesi yang dimiliki. Selain itu juga dinilai dari keahlian lanjutan yang disandangnya. Elemen dari keahlian 
profesional ini adalah ketaatan terhadap kode etik profesional, pengetahuan, ketrampilan, dan disiplin ilmu, hubungan dan komunikasi antar manusia, dan pendidikan berkelanjutan. Pada teori atribusi keahlian profesi merupakan salah satu faktor internal dalam menentukan karakteristik seseorang. Hal ini berarti semakin tinggikeahlian profesi yang dimiliki seorang pengawas maka semakin baik kinerjanya.

Hasil penelitian ini sesuai dengan penelitian yang dilakukan oleh Mappinyuki (2016) yang menyebutkan bahwa keahlian profesi berpengaruh positif terhadap kinerja. Penelitian lain yang diambil dari Kalbers dan Fogarty (1995), Aditya dan Wirakusuma (2014), Rahayu (2016), Meilina dkk., (2017) menunjukkan hasil yang sama.

Berdasarkan Tabel 6 diperoleh nilai signifikasi uji t satu sisi untuk variabel motivasi kerja (Mov) sebesar 0,00 maka tingkat signifikasi t pada uji satu sisi adalah 0,00 lebih kecil dari $\alpha=0,05$ dan nilai koefisien regresi sebesar 0,419 hal ini mengindikasikan bahwa motivsai kerja (Mov) berpengaruh positif dan signifikan pada kinerja pengawas (Y) sehingga hipotesis tiga dalam penelitian ini diterima.

Hasil penelitian ini membuktikan bahwa teori atribusi dan motivasi kerja berpengaruh pada kinerja pengawas. Motivasi dapat membuat seseorang mempunyai semangat juang yang tinggi untuk meraih tujuan dan memenuhi standar yang ada. Semakin tinggi motivasi pengawas, semakin membantu pengawas dalam menjalankan tugasnsya menemui bukti serta fakta dalam mendeteksi kekeliruan yang terkandung dalam laporan keuangan, sehingga 
Putu Kodyawati dan Luh Gede Krisna Dewi. Pengaruh ...

pengendalian intern dapat berjalan dengan efektif (Goleman \& Efendy, 2010). Pada teori atribusi motivasi kerja merupakan salah satu factor internal dalam menentukan karakteristik seseorang. Hal ini berarti semakin tinggi motivasi kerja yang dimiliki seorang pengawas maka semakin baik kinerjanya.

Hasil penelitian ini bersesuaian dengan penelitian yang dilakukan oleh Widyantara (2017) yang menyebutkan bahwa motivasi berpengaruh positif terhadap kinerja. Penelitian lain yang diambil dari Meilina dkk (2017) dan Ariza (2017) menunjukkan hasil yang sama.

Berdasarkan Tabel 6 diperoleh nilai signifikasi uji t satu sisi untuk variabel pengalaman kerja (Peng) sebesar 0,00 maka tingkat signifikasi t pada uji satu sisi adalah 0,00 lebih kecil dari $\alpha=0,05$ dan nilai koefisien regresi sebesar 0,198 hal ini mengindikasikan bahwa pengalaman kerja (Peng) berpengaruh positif dan signifikan pada kinerja pengawas (Y) sehingga hipotesis keempat dalam penelitian ini diterima.

Hasil penelitian ini membuktikan bahwa teori atribusi dan pengalaman kerja berpengaruh pada kinerja pengawas. Pengalaman auditor merupakan suatu proses pembelajaran dan perkembangan potensi bertingkah laku auditor selama berinteraksi dengan tugas yang dilakukan selama rentang waktu tertentu. Pengalaman kerja merupakan faktor penting dalam memprediksi dan menilai kinerja internal auditor dalam melakukan pemeriksaan intern. Pengawas yang berpengalaman akan lebih cepat tanggap dalam mendeteksi kekeliruan yang terjadi. Menurut Koroy (2005:917) semakin berpengalaman seorang internal auditor maka semakin mampu menghasilkan kinerja yang baik dalam tugasnya. 
Pada teori atribusi pengalaman kerja merupakan salah satu factor internal dalam menentukan karakteristik seseorang. Hal ini berarti semakin tinggi pengalaman kerja yang dimiliki seorang pengawas maka semakin baik kinerjanya.

Hasil penelitian ini bersesuaian dengan Yudha dan Mimba (2017) yang menyebutkan bahwa pengalaman yang dimiliki auditor berpengaruh terhadap kualitas audit. Budiasih dan Budiartha, (2017), dan Ariza (2017) mendapatkan hasil yang serupa.

Berdasarkan Tabel 5 diperoleh nilai signifikasi uji t satu sisi untuk variabel tingkat pendidikan (Pend) sebesar 0,00 maka tingkat signifikasi t pada uji satu sisi adalah 0,00 lebih kecil dari $\alpha=0,05$ dan nilai koefisien regresi sebesar 0,411 hal ini mengindikasikan bahwa tingkat pendidikan (Pend) berpengaruh positif dan signifikan pada kinerja pengawas $(\mathrm{Y})$ sehingga hipotesis kelima dalam penelitian ini diterima.

Hasil penelitian ini membuktikan bahwa teori atribusi dan tingkat pendidikan berpengaruh pada kinerja pengawas. Menurut Lisna (2007:92) pendidikan membentuk dan menambah pengetahuan seseorang untuk mengerjakan sesuatu lebih baik dan tepat. Seorang pengawas koperasi dalam melaksanakan kegiatan pengawasannya harus mempunyai pendidikan, keahlian dan disiplin. Pegawas koperasi yang ahli akan bekerja dengan teliti dan mengetahui dengan cepat penyimpangan yang terjadi dan tepat waktu dalam melaksanakan pengawasan. Pada teori atribusi tingkat pendidikan merupakan salah satu factor internal dalam menentukan karakteristik seseorang. Hal ini berarti semakin tinggi tingkat pendidikan yang dimiliki seorang pengawas maka semakin baik kinerjanya. 
Putu Kodyawati dan Luh Gede Krisna Dewi. Pengaruh ...

Hasil penelitian ini bersesuaian dengan penelitian yang dilakukan oleh Widyantara (2017) yang menyebutkan bahwa pendidikan berpengaruh terhadap hasil audit serta Meilina dkk., (2017) mendapatkan hasil yang serupa.

\section{SIMPULAN}

Independensi berpengaruh positif terhadap kinerja pengawas. Hal ini berarti semakin tinggi independensi maka kinerja pengawas semakin baik. Keahlian profesi berpengaruh positif terhadap kinerja pengawas. Hal ini berarti semakin tinggi keahlian profesi maka kinerja pengawas semakin baik. Motivasi kerja berpengaruh positif terhadap kinerja pengawas. Hal ini berarti semakin tinggi motivasi kerja maka kinerja pengawas semakin baik. Pengalaman kerja berpengaruh positif terhadap kinerja pengawas. Hal ini berarti semakin tinggi pengalaman kerja maka kinerja pengawas semakin baik.

Tingkat pendidikan berpengaruh positif dan signifikan terhadap kinerja pengawas. Hal ini berarti semakin tinggi tingkat pendidikan maka kinerja pengawas semakin baik.

Hasil penelitian diharapkan mampu memberikan informasi terhadap pengawas tentang independensi, keahlian profesi, motivasi kerja, pengalaman kerja dan tingkat pendidikan yang memiliki pengaruh dalam efisiensi kerja pengawas. Khususnya dalam pengambilan keputusan pengawas dalam menjalankan tugas dan wewenang.

Hasil penelitian juga diharapkan mampu memberikan gambaran kepada pengurus Koperasi di Kecamatan Klungkung untuk memperhatikan aspek 
independensi, keahlian profesi, motivasi kerja, pengalaman kerja dan tingkat pendidikan terhadap kinerja pengawas.

Hasil penelitian ini diharapkan mampu memberikan gambaran kepada pemerintah khususnya Dinas Koperasi dan UKM Kabupaten Klungkung bahwa keberhasilan koperasi juga dilihat dari kinerja pengawas. Sehingga, perlu memberikan informasi atau edukasi pada pengurus koperasi dalam memilih pengawas sehingga tujuan koperasi dapat terwujud.

Hasil penelitian ini agar dapat dijadikan referensi peniliti-peneliti selanjutnya dan dapat mereplikasi penelitian ini dengan menambah variabelvariabel lain yang dapat mempengaruhi kinerja pengawas seperti kompetensi, komitmen organisasi, dan lainnya.

Hasil penelitian ini terkendala pada partisipasi koperasi yang berada di Kecamatan Klungkung, sehingga diharapkan penelitian selanjutnya dapat mengambil strategi pemilihan lokasi penelitian.

\section{REFERENSI}

Ayu, I. G., Budiasih, N., \& Budiartha, K. (2017). Kemampuan Audit Tenure Memoderasi Hubungan Pengalaman Dan Skeptisisme Auditor Dengan Kualitas Audit, 2(1), 53-70.

Bouhawia, M. ., Irianto, G., \& Baridwan, Z. (2015). The Effect of Working Experience, Integrity, Competence, and Organizational Commitment on Audit Quality (Survey State Owned Companies In Libya). IOSR Journal of Economics and Finance, 6(4), 60-67.

Dawuda, A., Aninanya, G. O., \& Alnaa, S. E. (2015). The Organizational Independence of Internal Auditors in Ghana: Empirical Evidence from Local Government. Asian Journal of Economic Modelling, 3(2), 33-45. 
Halim, A., T, S., Rosidi, \& Achsin, M. (2014). Effect of competence and auditor independence on audit quality with audit time budget and professional commitment as a moderation variable. International Journal of Business and Management Invention, 3(6), 64-74.

Herda, D. N., \& Martin, K. a. (2016). The effects of auditor experience and professional commitment on acceptance of underreporting time: A moderated mediation analysis. Current Issues in Auditing, 10(2), A14-A27.

Herianto, Haming, M., \& Rahim, S. (2017). Influence of Commitments, Competencies, Ethics Auditor Working In Financial Supervisory Agency And Development Of South Sulawesi Province. Indonesia Journal of Business and Management, 3(2), 149-166.

Indra Arya Aditya, G.N. (2016). Kemampuan Komitmen Organisasi Dalam Memoderasi Pengaruh Profesionalisme dan Independensi Pada Kinerja Auditor (Studi Empiris Pada Kantor Akuntan Publik di Bali). Tesis. Fakultas Ekonomi dan Bisnis Universitas Udayana.

I, Widyantara, I. N., Wahyuni, M. A., \& Atmadja, A. T. (2017). Pengaruh Independensi, Motivasi, Kompetensi, dan Pengalaman Kerja Terhadap Kinerja Badan Pengawas Sebagai Auditor Internal Pada Lembaga Perkreditan Desa (LPD) di Kecamatan Buleleng, 1(2).

Kamau, C. G. (2014). Exploring Internal Auditor Independence Motivators: Kenyan Perspective. International Journal of Economics, Finance and Management Sciences, 2(2), 132.

Kanchanopast, S. (2013). Working Motivation Factors Affecting Job Performance Effectiveness. International Journal of Social, Management, Economics and Business Engineering, 7(8), 1175-1177.

Kotur, B. R., \& Anbazhagan, S. (2014). Education and Work-Experience Influence on the Performance. IOSR Journal of Business and Management Ver. III, 16(5), 2319-7668. Retrieved from www.iosrjournals.org

Laturkay. (2014). Independence And Objectivity Of Internal Auditing In The Private Joint Stock Companies In Yemen : A Field Study, (4), 159-166.

Made, T. N., \& Aryanto, D. (2016). Profesionalisme Sebagai Pemoderasi Pengaruh Independensi Pada Kinerja Auditor. E-Jurnal Akuntansi Univesitas Udayana, 14(3), 1895-1923.

Mariyanto, B. F. (2017). Pengaruh Kompetensi Dan Independensi Terhadap Kualitas Audit Dengan Etika Auditor Sebagai Variabel Moderasi Sugeng 
Praptoyo Sekolah Tinggi Ilmu Ekonomi Indonesia (Stiesia) Surabayak, 6, 761-779.

Meilvi Nasvita, D. (2016). The Factor That Effect on Internal Auditor Independence in the Aceh Banking Sector. International Multidisciplinary Journal, 33(1-2), 365-368.

Maslow, Abraham H., 1954. Motivation and Personality. New York: Harper and Bros

Murtini, N. N. (2017). Pengaruh Independensi, Keahlian Profesional, Pengalaman Kerja, dan Tingkat Pendidikan pada Kinerja Pengawas Koperasi Kecamatan Rendang Kabupaten Karangasem. Skripsi. Fakultas Ekonomi dan Bisnis Universitas Udayana.

Milica Đorđević, T. Đ. (2017). Independence And Objectivity Of Internal Auditors As Determinants Of Their Effectiveness, 14, 231-242.

Munawir, H.S. 2008. Auditing Modern. Buku 1. Yogyakarta: BPFE

Nur, S. W. (2017). The Influence of Independence and Competence of Auditor on the Performance of Inspectorate Auditors District MAROS, 6(10), 20152018.

Putra, I. G. A. D., \& Wisadha, I. G. S. (2012). Pengaruh Profesionalisme, Independensi, Dan Pengalaman Auditor Pada Kualitas Audit Badan Pengawas Lembaga Perkreditan Desa (LPD), 8(2), 89-98.

Putra, I. G. K. Y. P., \& Mimba, N. P. S. H. (2017). Pengaruh Locus Control, Pengalaman Kerja, Time Budget Pressure Dan Motivasi Auditor Pada Kualitas Audit. E-Jurnal Akuntansi Universitas Udayana, 18(2), 1286-1313.

Putra, P.B., \& N.K, R. (2014). Pengaruh Independensi, Kompetensi, dan Ruang Lingkup Pekerjaan Audit Pengawas pada Efektivitas Pengendalian Internal Koperasi, 3, 371-384.

Rahayu, T. (2016). Pengaruh Independensi Auditor , Etika Auditor , Dan Pengalaman Auditor Terhadap Kualitas Audit. Jurnal Ilmu Dan Riset Akuntasi, 5(April), 1-16.

Ratna Mappanyuki. (2016). Effects Spiritual Influence Of Auditors, Complexity Task, Ethics Auditor And Auditor Expertise On The Performance Auditor Withaccounting Information Systems With Moderating Variabel ( Empirical Study On Bpkp Representative Office South Sulawesi ). South East Asia Journal of Contemporary Bussines, Economics and Law, 9(1), 28-43. 
Safitri, M., \& Azlina, N, R. H. (2017). ). Pengaruh Pengertahuan Tentang Pengeloaan Keuangan, Objektivitas, Pengalaman Kerja Integritas dan Motivasi Terhadap Kualitas Audit (studi pada Inspektorat Kabupaten/Kota di Provinsi Riau). JOM Fekon, 4(1).

Saleem, K. A. (2018). The Impact of Internal Audit Committees 'Practices on Enhancing the Independence of Internal Auditors in Jordanian Commercial Banks. International Journal of Business and Management, 13(5), 156-170.

Sendhi Rahayu, N.M.S., \& I. D. . B. (2017). Pengaruh Locus of Control Internal, Motivasi Kerja, Gaya Kepemimpinan Transformasional, Komitmen Organisasi Pada Kinerja Auditor, 19, 2378-2406.

Septyaningtyas, W. A. (2017). Pengaruh Integritas, Motivasi, Objektivitas dan Pengalaman Kerja Terhadap Kualitas Audit (studi pada Inspektorat Kabupaten/Kota di Provinsi Riau). JOM Fekon, 4(1), 3471-3484.

Setiadi, Lutfhi. (2016). Pengaruh Kompetensi, Independensi, dan Motivasi Auditor Internal Terhadap Kualitas Audit Internal (Studi Empiris Pada Pt. Telekomunikasi Indonesia, Tbk). Skripsi. Fakultas Ekonomi dan Bisnis Universitas Pasundan

Simpen, I. W. (2015). Pengaruh Pengalaman dan Proses Reviu Pada Pertimbangan Auditor Dalam Menilai Penyajian Laporan Keuangan Pemerintah (Studi Pada Inspektorat di Provinsi Bali). Tesis. Fakultas Ekonomi dan Bisnis Universitas Udayana.

Shamki, D., \& Amur Alhajri, T. (2017). Factors Influence Internal Audit Effectiveness. International Journal of Business and Management, 12(10), 143.

Sohail, A., Safdar, R., Saleem, S., Ansar, S., \& Azeem, M. (2014). Effect of Work Motivation and Organizational Commitment on Job Satisfaction: (A Case of Education Industry in Pakistan). Global Journal of Management And Business Research, 14(6), 41-46.

Sudiksa, I. W., \& Utama, I. M. K. (2016). Profesionalisme, Motivasi dan Kepuasan Kerja Sebagai Prediktor Kinerja Internal Auditor (Toyota Astra Motor Wilayah Bali), 16(1), 733-755.

Tepalagul, N., \& Lin, L. (2015). Auditor Independence and Audit Quality: A Literature Review. Journal of Accounting, Auditing and Finance, 30(1), $101-121$.

Wahyuni Nur, Sri., \& Fitri. (2015). The Influence of Independence and Competence of Auditor on The Performance of Inspectorate Auditors 
ISSN: 2302-8556

E-Jurnal Akuntansi Universitas Udayana Vol.27.2.Mei (2019): 1597-1627

District Maros. International Journal of Science and Research. 2319-7064. 